А. Д. Беденюк, О. Л. Ковальчук, В. Б. Доброродній, Л. Є. Війтович

ДВНЗ “Тернопільський державний медичний університет

імені I. Я. Горбачевського МОЗ України”

\title{
МАТРИКУЛ ПРАКТИЧНИХ НАВИЧОК ЯК СКЛАДОВА ЧАСТИНА ПРАКТИЧНОЇ ПІДГОТОВКИ СТУДЕНТІВ НА КАФЕДРІ ХІРУРГІЇ № 1 3 УРОЛОГІЄЮ ТА МАЛОІНВАЗИВНОЮ ХІРУРГІЕЮ ІМЕНІ ПРОФЕСОРА Л. Я. КОВАЛЬЧУКА
}

A. D. Bedenyuk, O. L. Kovalchuk, V. B. Dobrorodniy, L. E. Viytovych I. Horbachevsky Ternopil State Medical University

\section{MATRICULA OF PRACTICAL SKILLS AS A PART OF THE PRACTICAL TRAINING OF STUDENTS AT L. YA. KOVALCHUK DEPARTMENT OF SURGERY №1 WITH UROLOGY AND MINIMALLY INVASIVE SURGERY}

\begin{abstract}
Мета дослідження - акцентувати увагу на важливості оволодіння практичними навичками в процесі навчання студентівмедиків.

Матеріали та методи дослідження. Аналіз літературних джерел та власного досвіду роботи за методикою “єдиного дня” 3 використанням матрикула практичних навичок.

Результати й обговорення. Методика “єдиного дня” значно розширила можливості навчального процесу в клініках та дозволила пристосовувати його до роботи спеціалізованих хірургічних відділень. На кафедрі хірургії № 1 з урологією та малоінвазивною хірургією імені професора Л. Я. Ковальчука ДВНЗ “Тернопільський державний медичний університет імені I. Я. Горбачевського МОЗ України” практичні заняття включають оволодіння студентами спеціальними навичками обстеження, постановки діагнозу та визначення лікувальної тактики у хворих з різною хірургічною патологією. Студенти беруть участь в інструментальних і апаратних методах обстеження одного із пацієнтів відділення за темою заняття, а також у діагностичнолікувальних процедурах. Протягом заняття викладач приймає практичні навички, які включені у матрикули практичних навичок та є складовою частиною комплексної підготовки студентів.

Висновки. Десятирічний досвід застосування даної методики проведення занять дозволив підвищити ефективність навчального процесу. Студенти мають змогу отримати не лише теоретичну підготовку, а й в обов'язковому порядку оволодіти практичними навичками, що сприяє поліпшенню розуміння та засвоєння матеріалу, розвитку клінічного мислення.
\end{abstract}

Ключові слова: матрикул практичних навичок; методика “єдиного дня”; студенти.

The aim of the study - to emphasize the importance of mastering practical skills in teaching medical students.

Materials and Methods. Analysis of the literature and personal experience of the technique of "one day" using Matricula of practical skills.

Results and Discussion. The method of "one day" greatly enhanced the learning process in hospitals and allowed to adapt it to the work of specialized surgical departments. In L. Ya. Kovalchuk Department of Surgery №1 with Urology and Minimally Invasive Surgery of Ternopil State Medical University the practical training includes mastering special skills examination, diagnosis and determining the treatment strategy in patients with various surgical pathology. Students participate in instrumental and hardware methods of examination of one of the patients of the topic sessions, and participate in diagnostic and therapeutic procedures. During the lesson the teacher takes the practical skills which involved in Matricula of practical skills and is a part of the comprehensive training of students.

Conclusions. Ten years of experience with this technique allowed to increase the effectiveness of the educational process. Students have the opportunity to receive not only theoretical knowledge but necessarily learn practical skills that improves understanding and learning, the development of clinical thinking. Matricula of practical skills is a part of the comprehensive training of students.

Key words: matricula of practical skills; method of “one day”; students.

Вступ. Навчання на робочому місці залишається наріжним каменем клінічної підготовки. Навчання в клінічному середовищі сприяє активній участі студента в роботі з пацієнтом, дозволяє об’єднати свої навички (збір анамнезу, даних об’єктивного обстеження та проведених додаткових досліджень), щоб визначити діагноз та відповідну тактику ведення пацієнта, формує клінічне мислення. Навчання,

( ) А. Д. Беденюк, О. Л. Ковальчук, В. Б. Доброродній, Л. Є. Війтович 
основане на практиці, є основним аспектом розвитку клінічної та професійної компетентності в галузі охорони здоров’я. Системи навчання, основані на практиці, мають багато взаємодіючих компонентів, але ключовим аспектом є робота з пацієнтом [1, 3, 4].

Мета дослідження - акцентувати увагу на важливості оволодіння практичними навичками в процесі навчання студентів-медиків.

Матеріали та методи дослідження. Аналіз літературних джерел та власного досвіду роботи за методикою “єдиного дня” з використанням матрикула практичних навичок.

Результати й обговорення. Методика “єдиного дня” значно розширила можливості навчального процесу в клініках, оскільки практичне заняття, яке включає в себе велику кількість нозологічних форм, дозволяє легше підібрати пацієнта, що відповідає темі заняття. Велика тривалість заняття (6 год) дозволяє легко пристосовувати навчальний процес у кожній конкретній групі до роботи клініки та спеціалізованих хірургічних відділень. Це дає змогу більш детально знайомити студентів з рутинною роботою відділення у всіх її аспектах. Студент протягом заняття має змогу побувати в операційній, перев’язочній, оглядовій, діагностичних кабінетах, не порушуючи їх графіки роботи.

Кожне практичне заняття розподілене на практичну частину, семінарське обговорення та самостійну роботу. Програма виконання практичної частини заняття на кафедрі хірургії № 1 з урологією та малоінвазивною хірургією імені професора Л. Я. Ковальчука включає курацію хворого з патологією по одній з тем заняття; участь в інструментальних і апаратних методах обстеження одного із пацієнтів відділення за темою заняття (рентгенографія або ендоскопія, ультразвукове дослідження, комп’ютерна томографія та ін.), а також участь у діагностично-лікувальних процедурах (перев’ язки, пункції, інгаляції, налагодження аспіраційної системи, постановка зонда, сечового катетера та інших маніпуляцій, присутність під час виконання операції та ін.).

На кафедрі хірургї̈ № 1 з урологією та малоінвазивною хірургією імені професора Л. Я. Ковальчука ТДМУ практичні заняття включають оволодіння студентами спеціальними навичками обстеження та лікування хірургічних хворих. Студент здійснює курацію реального пацієнта з патологією по одній із тем заняття, що передбачає збір анамнезу, проведення об’ єктивного обстеження, постановку діагнозу та визначення тактики лікування.
3 метою кращого оволодіння навичками та ознайомлення зі спеціальними діагностично-лікувальними методиками під час практичної частини студенти не обмежені у свої пересуваннях, вони можуть вільно відвідувати будь-які діагностичні кабінети клініки разом із пацієнтом.

Протягом заняття викладач приймає практичні навички, що включені в матрикулярну книжку та відповідають темі заняття.

Матрикул практичних навичок - це перелік практичних навичок, який складений кафедрою на основі галузевих стандартів освіти (освітньокваліфікаційної характеристики) і є обов’язковим для опанування студентами протягом навчального року [2]. Практичні навички розподілені по курсах, які у матрикулах названі лініями. Рік навчання відповідає номеру лінії. Завдяки їм викладачі після закінчення курсу бачать рівень засвоєння практичних навичок кожним студентом. Перелік та рівень засвоєння практичних навичок викладають у матрикулярній книжці, яка видається окремо для кожного курсу, і весь перелік їх є обов’язковим для виконання студентами, які на ньому навчаються. Без цього вони не будуть переводитися на наступний курс. Перший рівень - це теоретичне знання усіх етапів виконання практичної навички. Другий рівень передбачає, окрім знання і розуміння усіх етапів виконання практичної навички, хоча б одноразове бачення ії̈ виконання на практиці (виконання маніпуляції, процедури або пацієнта з відповідним захворюванням тощо). Третій рівень передбачає виконання навички на муляжі, фантомі чи в лабораторних умовах. Четвертий рівень вимагає проведення студентом маніпуляції (діагностичної чи лікувальної процедури, курації хворого тощо) під контролем викладача. П'ятий рівень освоєння виставляється за умови самостійного виконання студентом практичної навички.

На кафедрі хірургії № 1 з урологією та малоінвазивною хірургією імені професора Л. Я. Ковальчука навчаються студенти четвертого, п’ятого та шостого курсів, що відповідає четвертій, п’ятій та шостій лініям практичних навичок. На четвертому курсі студенти зобов’язані оволодіти методикою катетеризації сечового міхура еластичним катетером, визначення симптомів подразнення очеревини, гострої хірургічної абдомінальної патології та провести курацію хворих з килою, сечокам'яною хворобою, гострою затримкою сечі.

На п’ятому курсі в матрикулярній книжці обов’язковими практичними навичками є курація 
хворих $з$ травмою грудної клітки, деструктивними захворюваннями легень та плеври, варикозним розширенням вен нижніх кінцівок, флебітом та тромбофлебітом.

Шестикурсники проводять курацію хворих із шлунково-кишковими кровотечами, патологією прямої кишки, нагнійними процесами легень та плеври, облітеруючими захворюваннями судин нижніх кінцівок, хворих на перитоніт, гострий панкреатит, гостру кишкову непрохідність.

Висновки. Десятирічний досвід застосування даної методики проведення занять дозволив під-

\section{Список літератури}

1. Ковальчук Л. Я. Результати реалізації концепції розвитку Тернопільського державного медичного університету імені I. Я. Горбачевського на шляху його входження у світовий освітній простір / Л. Я. Ковальчук // Медична освіта. - 2011. - № 2. - С. 12-20.

2. Мисула I. Р. Про впровадження у навчальний процес ліній практичних навичок (матрикулів) / I. Р. Мисула, О. Є. Федорців // Медична освіта. - 2007. - № 2. С. 30-32.

\section{References}

1. Kovalchuk, L.Ya. (2011). Rezultaty realizatsii kontseptsii rozvytku Ternopilskoho derzhavnoho medychnoho universytetu imeni I. Ya. Horbachevskoho na shliakhu vkhodzhennia u svitovyi osvitniy prostir [Results of the concept of I. Ya. Horbachevskyi Ternopil State Medical University towards its entry into the world educational space]. Medychna osvita - Medical Education, 2, 12-20 [in Ukrainian].

2. Mysula, I.R. \& Fedortsiv, O.Ye. (2007). Pro vprovadzhennia u navchalnyi protses liniy praktychnykh navychkiv (matrykuly) [On introduction in educational pro- вищити ефективність навчального процесу. Студенти мають змогу отримати не лише теоретичну підготовку, а й в обов'язковому порядку оволодіти практичними навичками, що сприяє поліпшенню розуміння та засвоєння матеріалу, розвитку клінічного мислення.

Перспективи подальших досліджень. Пошук та впровадження в навчальний процес нових методик для кращого оволодіння студентами практичними вміннями.

3. Eliot L. Rees. WATCH Scrubs: a video observational study of workplace-based learning at Sacred Heart Hospital / Eliot L. Rees, Yashashwi Sinha, Benjamin Davies and Patrick J. Quinn // Medical Education. - 2016. - Vol. 50, № 12. - P. 195-1199.

4. Martin Tolsgaard G. Practical trials in medical education: linking theory, practice and decision making / Martin G. Tolsgaard, Kulamakan M. Kulasegaram, Charlotte Ringsted // Medical Education. - 2017. - Vol. 51, № 1. - P. 22-30.

cess of practical skills]. Medychna osvita-Medical Education, 2, 30-32 [in Ukrainian].

3. Eliot L. Rees, Yashashwi Sinha, Benjamin Davies and Patrick J. Quinn (2016). WATCH Scrubs: a video observational study of workplace-based learning at Sacred Heart Hospital. Medical Education, 50 (12), 1195-1199.

4. Martin G. Tolsgaard, Kulamakan M. Kulasegaram and Charlotte Ringsted (2017). Practical trials in medical education: linking theory, practice and decision making. Medical Education, 51 (1), 22-30.

Отримано 30.01.17 